\title{
Pengaruh Strategi Pemasaran terhadap Keputusan Pembelian Semen (Study Kasus pada PT. Semen Baturaja (Persero) Tbk)
}

\author{
Nenny Octarinie \\ Dosen Fakultas Ekonomi Universitas Palembang
}

\begin{abstract}
ABSTRAK
Penelitian ini bertujuan untuk mengetahui pengaruh strategi pemasaran terhadap keputusan pembelian semen (Study Kasus pada PT. Semen Baturaja (Persero) Tbk). Sampel pada penelitian ini berjumlah 100 responden. Data yang digunakan adalah data primerdan data sekunder yang dianalisis dengan menggunakan persamaan regresi linier bergandaa, uji hipotesis (uji t dan uji f), serta koefisien determinasi $\left(\mathrm{R}^{2}\right)$. Hasil penelitian diperoleh $\mathrm{Y}=3,327+0,504 \mathrm{X} 1+0,321 \mathrm{X} 2+$ $0,345 \mathrm{X} 3+0,519 \mathrm{X} 4$. Konstanta sebesar 3,327 adalah keputusan konsumensebelum dipengaruhi oleh variabel strategi pemasaran. Hasil perhitungan menunjukkan nilai $\mathrm{R}^{2}=0,547$. Hal ini berarti bahwa sebesar 54,7\% variasi naik turunnya keputusan konsumen dipengaruhi variabel Strategi Pemasaran . Sedangkan sisanya sebesar 45,3\% dipengaruhi oleh variabel lain yang tidak terdapat pada penelitian ini.
\end{abstract}

\section{Kata Kunci : Strategi Pemasaran, Keputusan Pembelian}

\section{PENDAHULUAN}

\subsection{Latar Belakang}

Secara umum semua perusahaan bertujuan untuk mendapatkan keuntungan yang optimal, maka kegagalan dalam melaksanakan kegiatan pemasaran akan membawa akibat-akibat yang cukup fatal bagi perusahaan. Usaha-usaha pemasaran untuk menguasai dan memperluas pasar mempunyai arti yang sangat penting, untuk itu perlu ditempuh berbagai cara demi mencapai tujuan tersebut.

Penjualan semen di Indonesia terus tumbuh mengikuti perekonomian nasional serta pembangunan infrastruktur danproperti. Dengan kondisi infrastruktur di Indonesia yangmasih kurang memadai, industri semen makin prospektif karena akan banyak dibutuhkan seiring percepatan pembangunan infrastruktur yang dicanangkan pemerintah. Peningkatan penjualan semen di wilayah Sumatera Selatan tercatat mengalami peningkatan.Hal ini mengindikasikan adanya peningkatan investasi dalam bentuk pembangunan konstruksi.

Peningkatan penjualan Semen Baturaja melampaui angka pertumbuhan pasar nasional. Kenaikan ini memperlihatkan bahwa konsumen mengenal baik merek Holcim yang menjalankan kegiatan usaha terpadu serta mampu menyediakan produk berkualitas dengan harga bersaing. Berikut adalah tabel peningkatan penjualan semen Baturaja secara domestik dari tahun $2018-2020$ :

Tabel 1.1

Peningkatan Penjualan Semen Baturaja

\begin{tabular}{|c|c|}
\hline Tahun & Total \\
\hline 2017 & 69,37 juta Ton \\
\hline 2018 & 75,23 juta Ton \\
\hline 2019 & 76,14 juta ton \\
\hline 2020 & 62,7 juta ton \\
\hline
\end{tabular}

Sumber : http://semenbaturaja.co.id

PT. Semen Baturaja (Persero) Tbk, merupakan salah satu industri semen terbesar di Sumatera Selatan. Perusahaan ini merupakan kelompok Semen Indonesia 
dengan beberapa perusahaan lainnya antara lain semen Andalas, Indocement, Cibinong, Bosowa, dan Kupang yang saling bersaing dalam merebut pangsa pasar di Indonesia. Keperluan semen di pasaran mengalami persaingan dengan perusahaan yang bergerak di bidang yang sama. Meningkatnya permintaan semen untuk infrastruktur dan perumahan menyebabkan PT. Semen Baturaja (Persero) Tbkberupaya untuk terus meningkatkan produksi dan distribusi semen ke berbagai penyalur dan toko bangunan yang menjual stok dalam melayani pihak pelanggan.

Upaya yang dilakukan untuk penjualan Semen Baturaja yang bersaing dengan perusahaan semen lainnya, berupaya untuk menjual semen sesuai dengan target produksi yang dihasilkan setiap hari.Hal ini berarti PT. Semen Baturaja (Persero) Tbkdalam menerapkan strategi pemasaran mampu melewati target yang ditetapkan, sehingga penting untuk diketahui pengaruh penerapan strategi pemasaran yang dilihat dari aspek segmentasi, target dan posisi pasar terhadap peningkatan pangsa pasar.

Strategi pemasaran yang dilakukan oleh pihak PT. Semen Baturaja (Persero) Tbksebagai solusi untuk mengatasi permasalahan dalam meraih pangsa pasar pada penjualan produk semen. Melalui strategi pemasaran dengan menggunakan konsep 4P (product, price, place dan promotion). Konsep ini digunakan untuk menerapkan strategi pemasaran dalam memenangkan persaingan pasar.

PT. Semen Baturaja (Persero) Tbkmampu mengemban visi, misi dan tujuannya dalam rangka meningkatkan pangsa pasar penjualan. Pihak pimpinan manajemen bersama dengan karyawannya berupaya menerapkan strategi pemasaran sebagai strategi inti atau strategi kunci untuk meningkatkan pangsa pasar. Berdasarkan uraian di atas, peneliti tertarik untuk melakukan penelitian dengan judul:
"Pengaruh Strategi Pemasaran terhadap Keputusan Pembelian Semen(Study Kasus pada PT. Semen Baturaja (Persero) Tbk)".

\subsection{Perumusan Masalah}

Berdasarkan uraian pada latar belakang tersebut di atas, maka rumusan masalah penelitian ini adalah:

1. Apakah strategi pemasaran yang terdiri atas produk, harga, promosi dan distribusi secara simultan berpengaruh terhadap keputusan pembelian Semen pada PT. Semen Baturaja (Persero) Tbk ?

2. Apakah strategi pemasaran yang terdiri atas produk, harga, promosi dan distribusi secara parsial berpengaruh terhadap keputusan pembelian Semen pada PT. Semen Baturaja (Persero) Tbk?

3. Faktor mana yang dominan mempengaruhi keputusan pembelian Semen pada PT. Semen Baturaja (Persero) Tbk?

\subsection{TUJUAN PENELITIAN}

Berdasarkan pada rumusan masalah tersebut, maka tujuan penelitian ini adalah:

1. Untuk mengetahui pengaruh strategi pemasaran yang terdiri atas produk, harga, promosi dan distribusi secara simultan terhadap keputusan pembelian Semen pada PT. Semen Baturaja (Persero) Tbk

2. Untuk mengetahui pengaruh strategi pemasaran yang terdiri atas produk, harga, promosi dan distribusi secara parsial terhadap keputusan pembelian Semen pada PT. Semen Baturaja (Persero) Tbk ?

3. Untuk mengetahui faktor yang dominan mempengaruhi keputusan pembelian Semen pada PT. Semen Baturaja (Persero) Tbk? 


\section{TINJAUAN PUSTAKA}

\subsection{LANDASAN TEORI}

\section{A. Manajemen Pemasaran}

Kegiatan pemasaran bagi suatu perusahaan merupakan salah satu kegiatan pokok yang harus dilakukan untuk mempertahankan kelangsungan hidupnya. Ada beberapa pendapat mengenai pengertian pemasaran diantaranya:

1. Kotler, Philip (2018: 4) mengemukakan "Pemasaran adalah proses sosial dan manajerial yang didalamnya individu atau kelompok memperoleh apa yang mereka butuhkan dan inginkan dengan menciptakan, menawarkan, dan menukarkan produk yang bernilai dengan pihak lain".

2. Nitisemito, Alex (2018: 13) yaitu: "Pemasaran adalah semua kegiatan yang bertujuan untuk memperlancar arus barang/jasa ke konsumen secara efisien dengan maksud untuk menciptakan permintaan secara efektif'.

3. William, Stanton J. (Winardi, 2019 :37) yang mengemukakan definisi pemasaran sebagai berikut: "Pemasaran adalah sistem keseluruhan dari kegiatan atau usaha yang ditujukan untuk merencanakan, menentukan harga, mempromosikan, dan mendistribusikan barang dan jasa yang dapat memuaskan pembeli yang ada maupun pembeli potensial."

Pengertian diatas menunjukkan bahwa pemasaran merupakan perpindahan arus barang dan jasa dari tangan produsen ke tangan pelanggan, perpindahan tersebut melahirkan suatu proses sosial yang dapat menciptakan kegunaan (utility), baik kegunaan tempat, waktu, dan kegunaan asal atau sesuai dengan penentuan harga, pemberian pelayanan, penetapan lokasi distribusi dan bersaing secara sehat.

\section{B. Strategi Pemasaran}

Basu Swastha dan Irawan (2018: 67) memberikan definisi strategi yaitu suatu rencana yang diutamakan untuk mencapai tujuan tersebut. Beberapa perusahaan mungkin mempunyai tujuan yang sama, tetapi strategi yang dipakai untuk mencapai tujuan tersebut dapat berbeda. Jadi, strategi dibuat berdasarkan tujuan". Menurut Kotler dan Gary Amstrong (2014: 5) inti pemasaran adalah mengidentifikasi dan memenuhi kebutuhan manusia dan sosial. Philip Kotler (2014 : 7) menyatakan bahwa: "Strategi pemasaran adalah pendekatan pokok yang akan digunakan oleh bisnis dalammencapai sasaran yangtelah ditetapkan lebih dulu; didalamnya tercantumkeputusan pokok mengenai target pasar, penempatan produk di pasar, bauran pemasaran dan tingkat biaya pemasaran yang diperlukan".

Terciptanya strategi pemasaran yang baik dapat memberikan beberapa manfaat diantaranya hubungan antara perusahaan dan pelanggannya menjadi harmonis, menjadikan pasar yang baik bagi pembelian danterciptanya loyalitas pelanggan, dan membentuk suatu rekomendasi dari mulut ke mulut ( word of mouth) yang menguntungkan bagi perusahaan (Kotler, 2019 : 97). Dalam dunia usaha, bentuk usaha apapun tentu tidak terlepas dari masalah ataupun hambatan dari dalam maupun luar perusahaan. Apabila hambatan tersebut berasal dari dalam perusahaan kemungkinan masih dapat diatasi atau dikendalikan oleh perusahaan itu sendiri. Namun bilamana hambatan itu berasal dari luar perusahaan, akan sulit untuk diatasi atau dikendalikan oleh perusahaan. Untuk itu langkah yang dapat ditempuh adalah dengan memperkuat posisi perusahaan dengan menyusun suatu strategi dalam menghadapi setiap masalah.

Oleh sebab itu perusahaan diharapkan dapat menentukan strategi pemasaran dan yang sangat penting adalah strategi yang terkait bauran pemasaran 
(marketing mix) yang dikenal dengan 4P yaitu product, price, promotion, and place/distribution. Untuk lebih jelasnya marketing mix yang meliputi kualitas, harga, promosi, dan distribusi akan diuraikan berikut ini :

\section{Produk (Product)}

Menurut Tjiptono (2015: 95) bahwa produk adalah segala sesuatu yang dapat ditawarkan produsen untuk diperhatikan, diminta, dicari, dibeli, digunakan atau dikonsumsi pasar sebagai pemenuhan kebutuhan atau keinginan pasar yang bersangkutan.

\section{Harga (Price)}

Menurut Basu dan Irawan (dalam Umar, 2013: 54) memberikan definisi mengenai harga sebagai berikut: "Harga adalah uang (ditambah beberapa produk kalau mungkin) yang dibutuhkan untuk mendapatkan sejumlah kombinasi dari produk dan pelayanannya." Menurut Kotler (2014 : 41) harga (price) merupakan nilai suatu barang dan jasa yang diukur dengan uang.

\section{Promosi (Promotion)}

Menurut Fandy Tjiptono (2015: 219), promosi adalah suatu bentuk komunikasi pemasaran. Yang dimaksud dengan komunikasi pemasaran tersebut adalah aktivitas pemasaran yang berusaha untuk menyebarkan informasi, mempengaruhi/ membujuk, dan atau meningatkan pasar sasaran atas perusahaan dan produknya agar berusaha menerima, membeli dan loyal pada produk yang ditawarkan perusahaan yang bersangkutan. Untuk mencapai hasil yang diharapkan perusahaan biasanya tidak hanya menggunakan satu elemen prornosi saja melainkan menggunakan bauran promosi yaitu kombinasi dari unsur-unsur sebagai berikut: a. Periklanan (Advertising)

b. Publisitas (Publicity)

c. Promosi Pembelian (Sales Promotion)

d. Pemasaran untuk kegiatan tertentu (event marketing)

\section{Distribusi (Place)}

Sebagian besar produsen menggunakan perantara pemasaran untuk memasarkan produknya terutama perusahaan yang memproduksi barang dalam jumlah yang besar dan jarak antara produsen dengan konsumen jauh.

\section{Pengambilan Keputusan Pembelian}

Menurut Terry (dalam Basu Swastha dan Irawan, 2018 : 27) bahwa "Pengambilan keputusan adalah sebagai penentuan pilihan yang didasari atas kriteria tertentu terhadap beberapa alternatif." Proses pengambilan keputusan membeli didefinisikan oleh Basu Swastha dan Irawan (2018 : 24) sebagai berikut "Serangkaian tindakan yang dilakukan oleh konsumendalam pengambilan keputusan tentang produkproduk manakah yang dibeli”

Dari definisi di atas diketahui bahwa perilaku konsumen itu akan menentukan proses pengambilan keputusan dalam pembelian mereka. Proses tersebut merupakan sebuah pendekatan penyelesaian masalah yang terdiri atas lima tahap proses yaitu:

1. Pengenalan Masalah Tahap pertama terdiri atas proses keputusan membeli adalah pengenalan (problem recognition).

2. Pencarian Informasi Tahap kedua adalah pencarian informasi (information search), muncul apabila konsumen mulai tergugah minatnya terhadap sesuatu untuk memenuhi kebutuhan maupun keinginannya.

3. Penilaian Alternatif/Evaluasi Alternatif. Dalam tahap ini tidak ada suatu proses penilaian sederhana dan tunggal yang 
dapat dipergunakan oleh semua konsumen.

4. Keputusan Membeli Tahap ini diawali dengan penilaian terhadap berbagai alternatif yang dapat dilihat dari atributatribut yang melekat padaproduk tersebut. Dengan indikasi itu maka konsumen membentuk pilihan. Dalam tahap ini konsumen dapat juga membentuk suatu maksud memilih produk yang disukai.

5. Perilaku Setelah Membeli Tahap kelima adalah perilaku setelah membeli. Setelah membeli suatu produk konsumen akan mengalami beberapa tingkat ketidakpuasan.

\subsection{Penelitian Terdahulu}

Analisis pengaruh strategi pemasaran dalam meningkatkan pangsa pasar pada PT.Semen Tonasa (Skripsi oleh Irwin Ariansyah, Universitas Hasanuddin Makasar 2014).Berdasarkan hasil penelitian tersebut diperoleh hasil bahwaPersamaan regresi di atas terdapat nilai konstanta sebesar 0.584 . Hal ini menunjukkan bahwa jika variabel independen dianggap konstan, maka penerapan strategi pemasaran segmentasi, targeting dan positioning berpengaruh terhadap pangsa pasar sebesar 3.237. Dari hasil perhitungan analisis Full Model Regression dengan bantuan program SPSS diperoleh Fhitung sebesar 78.954 dengan tingkat probabilitas 0.000 (signifikan).
Sedangkan Ftabel sebesar 4.9646 dengan demikian maka Fhitung lebih besar dari Ftabel (78.954 > 4.9646 dan juga probabilitas jauh lebih kecil dari 0.05 .

Penelitian selanjutnya yang dilakukan olehAlfian Surya Nuramsyah, Didik Eko Julianto, Yuslinda Dwi Handini, Jurusan Ilmu Administrasi, Fakultas Ilmu Sosial dan Ilmu Politik, Universitas Jember (UNEJ) dengan judul Pengaruh Bauran Pemasaran Terhadap Peningkatan Penjualan Semen Holcim Pada Gerai-Gerai PT. Panahmas Dwitama Distrindo Jemberdiperoleh hasil bahwa terdapat Pengaruh variabel produk, harga,tempat, promosi, orang, bukti fisik, dan proses ditunjukkan pada uji $t$ dengan nilai signifikansi lebih kecil dari 0,05, artinya variabel produk, harga, tempat, promosi, orang, bukti fisik, dan proses secara sendirisendiri memberikan pengaruh signifikan terhadap peningkatan penjualan semen pada outlet PT. Panahmas Dwitama Distrindo Divisi Holcim Jember. Berdasarkan tabel diatas, diketahui bahwa signifikansi $<0,05$ sehingga Ho ditolak dan Ha diterima, artinya semua variabel bebas (Independen), yaitu Produk (X1), Harga (X2), Tempat (X3), Promosi (X4), Orang (X5), Bukti Fisik (X6) dan Proses (X7) cara simultan (bersamasama) memiliki pengaruh positif terhadap variabel terikat (dependen), yaitu Peningkatan penjualan (Y).

\subsection{Kerangka Fikir}

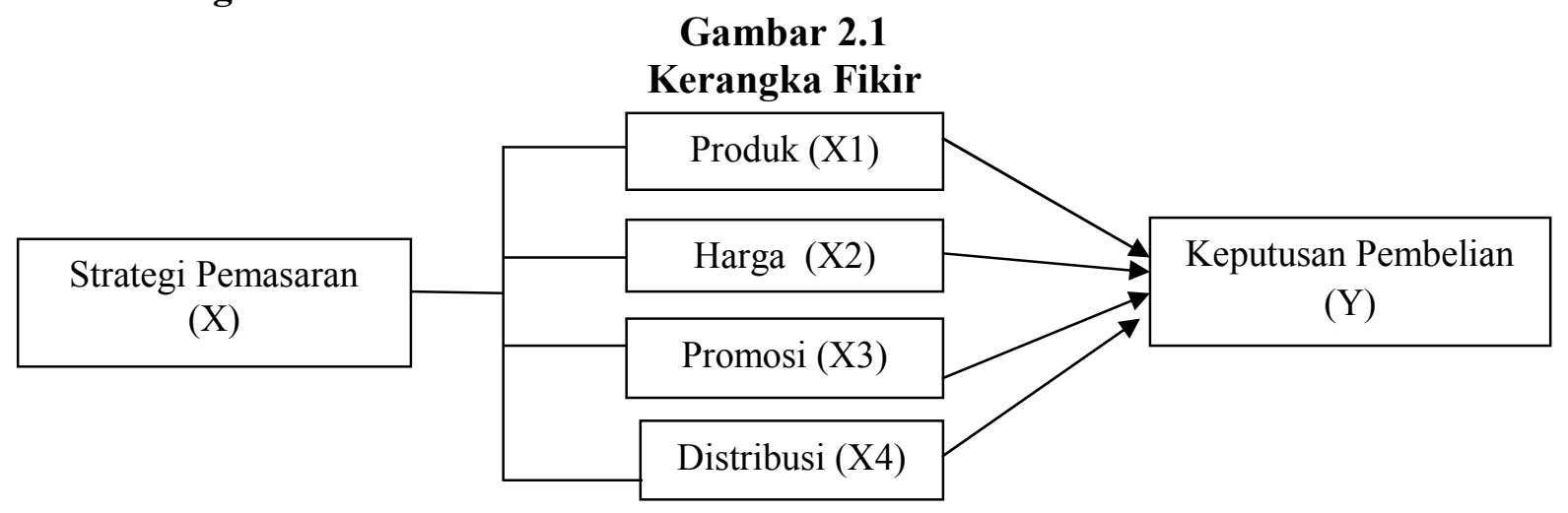

\section{Gambar 2.1}

gka Fiki 


\subsection{HIPOTESIS}

Hipotesis penelitian ini adalah sebagai berikut:

1. Diduga bahwa strategi pemasaran yang terdiri atas strategi produk, harga, promosi dan distribusi secara simultan berpengaruh terhadap keputusan pembelian Semen pada PT.Semen Baturaja (persero) Tbk

2. Diduga bahwa strategi pemasaran yang terdiri atas strategi produk, harga, promosi dan distribusi secara parsial berpengaruh terhadap keputusan pembelian Semen pada PT.Semen Baturaja (persero) Tbk

3. Diduga bahwa faktor produk yang dominan berpengaruh terhadap keputusan pembelian Semen pada PT.Semen Baturaja (persero) Tbk.

\section{METODOLOGI PENELITIAN}

3.1. OBJEK PENELITIAN

Adapun objek penelitian kali ini adalah PT.Semen Baturaja (Persero) Tbk dan waktu penelitian direncanakan bulan Desember sampai Mei 2021.

\subsection{RUANG LINGKUP PENELITIAN}

Untuk mempermudah penulis dalam melakukan pembahasan dan tidak menyimpang dari permasalahan yang ada, maka penulis membatasi ruang lingkup pembahasan hanya pada Strategi Pemasaran yang meliputi :

1. Product (Produk)

2. Price (Harga)

3. Place (Distribusi)

4. Promotion (Promosi)

\subsection{DESAIN PENELITIAN}

Penelitian ini dirancang untuk menjawab permasalahan yang telah dirumuskan dan tujuan yang hendak dicapai serta menguji hipotesis. Rancangan penelitian menurut M.Ruseffendi (2014:85) merupakan suatu struktur penyelidikan yang disusun sedemikian rupa, sehingga peneliti dapat memperoleh jawaban untuk pertanyaan-pertanyaan penelitian, dibedakan sebagai berikut:

1. Penelitian ini merupakan penelitian exploratory yaitu berusaha untuk mencari hubungan-hubungan yang relatif baru, dan explanatory yaitu penelitian yang dilakukan dengan cara menjelaskan gejala yang ditimbulkan oleh suatu obyek penelitian.

2. Ditinjau dari aspek datanya adalah penelitian ex post facto, yang berarti setelah kejadian yaitu penelitian yang bersifat pencarian empirik yang sistematik, di mana peneliti tidak dapat mengontrol variabel bebasnya karena peristiwa telah terjadi atau sifatnya tidak dapat dimanipulasi.

3. Ditinjau dari tujuannya adalah studi kausal yang berusaha menjelaskan analisis pengaruh strategi pemasaran terhadap keputusan konsumen pada PT.Semen Baturaja (Persero) Tbk

\subsection{JENIS DAN SUMBER DATA \\ a. Jenis Data}

Untuk menunjang pembahasan dalam penelitian ini, maka data yang digunakan adalah sebagai berikut :

1. Data Primer

Data primer adalah data yang dikumpulkan dan diperoleh secara langsung dari responden dengan menggunakan angket.

\section{Data Sekunder}

Data Sekunder adalah data yang diperoleh secara tidak langsung dari objek yang diteliti. Data ini diperoleh dari literatur, majalah serta dokumen yangberupa database pelanggan yang diperlukan untuk penyusunan penelitian ini 
b. Sumber Data

Teknik pengumpulan data yang digunakan adalah, observasi, kuesioner dan studi dokumentasi:

1. Observasi, yaitu teknik pengumpulan data di mana peneliti terlibat langsung untuk mengamati analisis pengaruh strategi pasar terhadap keputusan konsumen pada PT.Semen Baturaja (Persero) Tbk

2. Penyebaran kuesioner digunakan untuk mendapatkan data kuantitatif terdiri dari variabel bebas dan variabel terikat. Teknik pengukuran, menggunakan Skala Likert.

3. Studi dokumentasi yaitu teknik pengumpulan data dengan cara mempelajari buku-buku maupun jurnal yang berkaitan dengan topik pembahasan.

\subsection{POPULASI DAN SAMPEL}

\subsubsection{Populasi}

Populasi atau universe adalah keseluruhan unit analisis yang ciri- cirinya akan diduga. Populasi dalam penelitian ini adalah seluruh konsumen yang pernah melakukan pembelian Semen Baturaja dibeberapa toko di Kota Palembang sepanjang tahun 2020 .

\subsubsection{Sampel}

Sampel adalah bagian dari populasi yang terambil yang dianggap dapat mewakili seluruh populasi untuk diamati dan diukur. Ukuran sampel dalam penelitian ini berdasarkan pada pertimbangan Saefuddin Azwar (2017 : 54) menyatakan bahwa beberapa panduan untuk menentukan ukuran sampel adalah:

1. Ukuran sampel lebih dari 30 dan kurang dari 500 adalah tepat untuk kebanyakan penelitian

2. Dalam penelitian multivariate (termasuk analisis regresi berganda), ukuran sampel sebaiknya lebih besar dari 10 kali jumlah variabel dalam penelitian.

Dalam konteks penelitian ini terdapat 5 variabel penelitian sehingga sebaiknya jumlah sampel lebih dari 50 dan kurang dari 500. Berdasarkan pertimbangan tersebut penulis menetapkan jumlah sampel sebanyak100 orang. Teknik pengambilan sampel dari populasi tersebut adalah accidental random sampling yakni mengambil sampel dari setiap anggota populasi sasaran yang ditemui di lapangan

\subsection{DEFINISI OPERASIONAL DAN PENGUKURAN VARIABEL}

Tabel 3.1

Definisi Operasional Variabel

\begin{tabular}{|c|c|c|c|}
\hline Variabel & $\begin{array}{c}\text { Definisi Operasional } \\
\text { Variabel }\end{array}$ & Indikator & Parameter \\
\hline $\begin{array}{c}\text { Strategi } \\
\text { Pemasaran } \\
\text { (X) }\end{array}$ & $\begin{array}{l}\text { Pendekatan pokok yang } \\
\text { digunakan } \\
\text { perusahaan } \\
\text { oleh } \\
\text { memasarkan produknya } \\
\text { untuk mencapai tujuan } \\
\text { pemasaran. }\end{array}$ & $\begin{array}{ll}\text { 1. } & \text { Produk (X1) } \\
\text { 2. } & \text { Harga (X2) } \\
\text { 3. Distribusi (X3) } \\
\text { 4. } \text { Promosi (X4) }\end{array}$ & $\begin{array}{l}\text { 1. Produk (X1), terdiri dari } \\
\text { a. Performance } \\
\text { b. Fasilitas } \\
\text { c. Reabilitas } \\
\text { d. Konformasi } \\
\text { e. Usia Pakai } \\
\text { 2. Harga (X2) } \\
\text { a. Harga Beli } \\
\text { b. Daya Beli }\end{array}$ \\
\hline
\end{tabular}




\begin{tabular}{|c|c|c|c|}
\hline & & & $\begin{array}{l}\text { 3. Distribusi (X3) } \\
\text { a. Tempat Penjualan } \\
\text { b. Kecepatan } \\
\text { Pengadaan } \\
\text { 4. Promosi (X4) } \\
\text { a. Periklanan } \\
\text { b. Penjualan } \\
\text { Perorangan } \\
\text { c. Promosi Dagang } \\
\text { d. Publisitas }\end{array}$ \\
\hline $\begin{array}{c}\text { Keputusan } \\
\text { Pembeli } \\
\text { (Y) }\end{array}$ & $\begin{array}{l}\text { Serangkaian tindakan } \\
\text { yang dilakukan oleh } \\
\text { konsumendalam } \\
\text { pengambilan keputusan } \\
\text { tentang produk-produk } \\
\text { yang akan dibeli }\end{array}$ & $\begin{array}{l}\text { 1. Ketepatan } \\
\text { putusan } \\
\text { 2. Kepuasan } \\
\text { 3. Loyalitas }\end{array}$ & \\
\hline
\end{tabular}

\subsection{TEKNIK ANALISIS}

\subsubsection{Metode Analisis}

Untuk menguji hipotesis yang telah diajukan dalam penelitian ini, maka digunakan metode analisisregresi linier berganda:

$$
\begin{aligned}
& \mathrm{Y}=\mathrm{b} 0+\mathrm{b} 1 \mathrm{X} 1+\mathrm{b} 2 \mathrm{X} 2+\mathrm{b} 3 \mathrm{X} 3+\mathrm{e} \\
& \text { Dimana: } \\
& \mathrm{Y}=\text { Keputusan Konsumen } \\
& \mathrm{X} 1=\text { Produk } \\
& \mathrm{X} 2=\text { Harga } \\
& \mathrm{X} 3=\text { Distribusi } \\
& \mathrm{X} 4=\text { Promosi } \\
& \mathrm{b} 1-\mathrm{b} 4=\text { Koefisien Regresi (Parameter) } \\
& \mathrm{b} 0=\text { Konstanta (Intercept) } \\
& \mathrm{e}=\text { Faktor Kesalahan }
\end{aligned}
$$

\subsubsection{Pengujian Data}

\section{Uji Validitas}

Suatu instrumen penelitian mutlak dilakukan uji validitas (kesahihan) dan reliabilitas (kehandalan) sebelum digunakan dalam penelitian yang sesungguhnya. Suatu instrumen dikatakan valid bila mampu mengukur apa yang hendak diukur. (Saeffudin Azwar, 2017:77).

\section{Uji Reliabilitas}

Hasil uji reliabilitas kuesioner menunjukkan bahwa instrumen penelitian ini cukup reliable atau dapat dipercaya untuk digunakan sebagai alat dalam pengumpulan data dalam menganalisis kuesioner penelitiandengan hasil yang dapat dibuktikan bahwa sangat signifikan (reliable) dimana nilai $\mathrm{p}<0,05$ dengan taraf kemaknaan $\alpha=5 \%$.

\subsubsection{Pengujian Hipotesis}

1. Pengujian hipotesis 1 yaitu pengaruh variabel $\mathrm{X} 1, \mathrm{X} 2, \mathrm{x} 3$ dan $\mathrm{x} 4$ secara simultan terhadap $\mathrm{Y}$ dilakukan dengan menggunakan uji $\mathrm{F}$.

Jika nilai Fhit $<$ Ftabel atau nilai sig $>$ 0,05 maka $\mathrm{H} 0$ diterima (H1 ditolak) berarti tidak pengaruh $\mathrm{X} 1$ dan $\mathrm{X} 2, \mathrm{X} 3$ dan X4 secara simultan terhadap Y, sebaliknya jika nilai Fhit $>$ Ftabelatau nilai sig $<0,05$ maka $\mathrm{H} 0$ ditolak (H1 diterima) berarti ada pengaruh $\mathrm{X} 1, \mathrm{X} 2$, X3 dan X4 secara simultan terhadap Y

2. Pengujian hipotesis 2 yaitu pengaruh variabel X1 secara parsial terhadap $\mathrm{Y}$ 
digunakan uji t. Jika nilai thit $<$ ttabel atau nilai sig $>0,05$ maka $\mathrm{H} 0$ diterima (H1 ditolak) berarti tidak ada pengaruh X1 secara parsial terhadap Y. Sebaliknya jika nilai thit $>$ ttabel atau nilai sig $<0,05$ maka $\mathrm{H} 0$ ditolak $(\mathrm{H} 1$ diterima) berarti ada pengaruh X1 secara parsial terhadap Y. Dengan cara yang sama diperoleh ada tidaknya pengaruh X2 secara parsial terhadap $\mathrm{Y}$ dan pengaruh $\mathrm{X} 3$ secara parsial terhadap $\mathrm{Y}$ dan pengaruh $\mathrm{X} 4$ secara parsial terhadap $\mathrm{Y}$

3. Pengujian hipotesis 3 dilakukan dengan menggunakan perbandingan nilai koefisien pengaruh $\mathrm{X} 1, \mathrm{X} 2, \mathrm{X} 3$ dan $\mathrm{X} 4$ terhadap $\mathrm{Y}$ dalam persamaan regresi. Koefisien yang paling besar menunjukkan pengaruh yang dominan.

\subsubsection{Koefisien Determinasi}

Koefisien determinasi bertujuan untuk mengukur seberapa jauh kemampuan model dalam menerangkan variasi variabel dependen. Nilai koefisien determinasi adalah $0<\mathrm{R}^{2}<1$. Koefisien determinasi yang mendekati satu variabel independen memberikan hampir semua informasi yang dibutuhkan untuk memprediksi variabel dependen.

\section{HASIL PENELITIAN DAN PEMBAHASAN}

\subsection{Deskripsi Responden}

Responden dalam penelitian ini adalah seluruh konsumen yang pernah melakukan pembelian Semen Baturaja dibeberapa toko di Kota Palembang sepanjang tahun 2020. Adapun sampel yang digunakan adalah sejumlah 100 orang yang secara random ditemui oleh penulis pada saat penelitian berlangsung. Terdapat karakteristik responden yang dimasukkan dalam penelitian, yaitu berdasarkan usia, jenis kelamin tingkat pendidikan.

\section{a. Usia}

Pada tabel berikut ini menunjukkan pengelompokkan responden berdasarkanusia :

Tabel 4.1

Karakteristik Responden berdasarkan Usia

\begin{tabular}{|c|c|c|}
\hline Usia & Jumlah Responden & \% \\
\hline $19-25$ tahun & 3 & 3 \\
$26-30$ tahun & 17 & 17 \\
$31-35$ tahun & 27 & 27 \\
$>36$ tahun & 53 & 53 \\
\hline Total & 100 & 100 \\
\hline
\end{tabular}

Sumber : Data Primer (Kuesioner), diolah 2021

Dari tabel di atas yang berdasarkan usia, responden yang yang berumur $>36$ tahun merupakan yang paling banyak, yaitu 53 orang atau 53\% dan yang paling sedikit berumur 19-25 yaitu 3 orang atau hanya $3 \%$ saja. 


\section{b. Jenis Kelamin}

kelamin :

Pada tabel berikut ini menunjukkan pengelompokan responden berdasarkan pada jenis

Tabel 4.2

Karakteristik Responden berdasarkan Jenis Kelamin

\begin{tabular}{|c|c|c|}
\hline Jenis Kelamin & Jumlah Responden & $\%$ \\
\hline Laki-laki & 92 & 92 \\
Perempuan & 8 & 8 \\
\hline Total & 100 & 100 \\
\hline
\end{tabular}

Sumber : Data Primer (Kuesioner), diolah 2021

Dari data di atas dapat di ketahui yaitu responden laki-laki merupakan responden terbanyak yaitu 92 orang atau $92 \%$ dan hanya 8 orang atau $8 \%$ berjenis kelamin perempuan.

\section{c. Tingkat Pendidikan}

Pada tabel berikut ini menunjukkan pengelompokan responden berdasarkan pada tingkat pendidikan :

Tabel 4.3

Karakteristik Responden berdasarkan Tingkat Pendidikan

\begin{tabular}{|l|c|c|}
\hline \multicolumn{1}{|c|}{ Tingkat Pendidikan } & Jumlah Responden & $\mathbf{\%}$ \\
\hline SLTA & 13 & 13 \\
Diploma 3 / D3 & 26 & 26 \\
Strata 1 / S1 & 57 & 57 \\
Strata 2 / S2 & 4 & 4 \\
\hline \multicolumn{1}{|c|}{ Total } & 100 & 100 \\
\hline
\end{tabular}

Sumber : Data Primer (Kuesioner), diolah 2021

Dari tabel di atas dapat kita ketahui bahwa berdasarkan tingkat pendidikan Strata 1 merupakan reponden paling banyak yaitu 57 orang atau $57 \%$, sedangkan yang paling rendah adalah pada tingkat pendidikan Strata 2 yaitu sebanyak 4 orang atau hanya $4 \%$ saja.

\subsection{Analisis Data}

A. Variabel Strategi Pemasaran

. Adapun persepsi mengenai Strategi Pemasaran dapat disajikan dalam bentuk tabel dibawah ini :

\section{Variabel Produk (X1)}

Tabel 4.4

Saya memilih semen baturaja karena memiliki kesesuaian dengan spesifikasi produk

\begin{tabular}{|c|c|c|}
\hline Tingkat Jawaban Responden & Jumlah & Persentase \\
\hline Sangat Setuju & 32 & 32 \\
\hline Setuju & 68 & 68 \\
\hline Netral & -- & -- \\
\hline Tidak Setuju & -- & -- \\
\hline Sangat Tidak Setuju & -- & -- \\
\hline TOTAL & 100 & $100 \%$ \\
\hline
\end{tabular}

Sumber : Data primer diolah 2021 
Berdasarkan tabel tersebut diatas maka dapat dijelaskan bahwa jawaban terbanyak dari responden adalah Setuju dengan jumlah responden sebanyak 68 orang atau sebesar $68 \%$ dan selanjutnya sebanyak 32 orang atau sebesar 32\% responden menyatakan Sangat Setuju.

Tabel 4.5

Kualitas semen baturaja lebih baik dibandingkan produk yang lain

\begin{tabular}{|c|c|c|}
\hline Tingkat Jawaban Responden & Jumlah & Persentase \\
\hline Sangat Setuju & 20 & 20 \\
\hline Setuju & 78 & 78 \\
\hline Netral & 2 & 2 \\
\hline Tidak Setuju & -- & -- \\
\hline Sangat Tidak Setuju & -- & -- \\
\hline TOTAL & 100 & $100 \%$ \\
\hline
\end{tabular}

Sumber : Data primer diolah 2021

Berdasarkan tabel tersebut diatas maka dapat dijelaskan bahwa jawaban terbanyak dari responden adalah Setuju dengan jumlah responden sebanyak 78 orang atau sebesar $78 \%$ dan selanjutnya sebanyak 20 orang atau sebesar $20 \%$ responden menyatakan Sangat Setuju dan sebanyak 2 orang atau sebesar $2 \%$ menyatakan netral terhadap pernyataan ini.

Tabel 4.6

Semen baturaja memiliki probabilitas suatu produk untuk beroperasi dengan baik pada suatu kurun waktu tertentu

\begin{tabular}{|c|c|c|}
\hline Tingkat Jawaban Responden & Jumlah & Persentase \\
\hline Sangat Setuju & 39 & 39 \\
\hline Setuju & 53 & 53 \\
\hline Netral & 8 & 8 \\
\hline Tidak Setuju & -- & -- \\
\hline Sangat Tidak Setuju & -- & -- \\
\hline TOTAL & 100 & $100 \%$ \\
\hline
\end{tabular}

Sumber : Data primer diolah 2021

Berdasarkan tabel tersebut diatas maka dapat dijelaskan bahwa jawaban terbanyak dari responden adalah Setuju dengan jumlah responden sebanyak 53 orang atau sebesar 53 \% dan selanjutnya sebanyak 39 orang atau sebesar 39\% responden menyatakan Sangat Setuju. 
Tabel 4.7

Semen baturaja memiliki Reliabilitas yang baik yang menandakan sedikitnya masalah/kegagalan kerusakan yang di dalam produk untuk kurun waktu tertentu

\begin{tabular}{|c|c|c|}
\hline Tingkat Jawaban Responden & Jumlah & Persentase \\
\hline Sangat Setuju & 44 & 44 \\
\hline Setuju & 47 & 47 \\
\hline Netral & 7 & 7 \\
\hline Tidak Setuju & 2 & 2 \\
\hline Sangat Tidak Setuju & -- & -- \\
\hline TOTAL & 100 & $100 \%$ \\
\hline
\end{tabular}

Sumber : Data primer diolah 2021

Berdasarkan tabel tersebut diatas maka dapat dijelaskan bahwa jawaban terbanyak dari responden adalah Setuju dengan jumlah responden sebanyak 47 orang atau sebesar $47 \%$ dan selanjutnya sebanyak 44 orang atau sebesar $44 \%$ responden menyatakan Sangat Setuju dan sebanyak 2 orang atau sebesar $2 \%$ menyatakan Tidak Setuju terhadap pernyataan ini.

Tabel 4.8

Desain dan performansi semen baturaja memiliki ukuran/standar baku yang dijadikan toleransi.

\begin{tabular}{|c|c|c|}
\hline Tingkat Jawaban Responden & Jumlah & Persentase \\
\hline Sangat Setuju & 47 & 47 \\
\hline Setuju & 50 & 50 \\
\hline Netral & 3 & 3 \\
\hline Tidak Setuju & -- & -- \\
\hline Sangat Tidak Setuju & -- & -- \\
\hline TOTAL & 100 & $100 \%$ \\
\hline
\end{tabular}

Sumber : Data primer diolah 2021

Berdasarkan tabel tersebut diatas maka dapat dijelaskan bahwa jawaban terbanyak dari responden adalah Setuju dengan jumlah responden sebanyak 50 orang atau sebesar $50 \%$ dan selanjutnya sebanyak 47 orang atau sebesar $47 \%$ responden menyatakan Sangat Setuju dan sebanyak 3 orang atau sebesar 3\% menyatakan Tidak Setuju terhadap pernyataan ini.

Tabel 4.9

Semen baturaja memiliki ketahanan produk yang cukup lama

\begin{tabular}{|c|c|c|}
\hline Tingkat Jawaban Responden & Jumlah & Persentase \\
\hline Sangat Setuju & 69 & 69 \\
\hline Setuju & 31 & 31 \\
\hline Netral & -- & -- \\
\hline Tidak Setuju & -- & -- \\
\hline Sangat Tidak Setuju & -- & -- \\
\hline TOTAL & 100 & $100 \%$ \\
\hline
\end{tabular}

Sumber : Data primer diolah 2021 
Berdasarkan tabel tersebut diatas maka dapat dijelaskan bahwa jawaban terbanyak dari responden adalah Sangat Setuju dengan jumlah responden sebanyak 69 orang atau sebesar $69 \%$ dan selanjutnya sebanyak 31 orang atau sebesar $31 \%$ responden menyatakan Setuju.

\section{Variabel Harga (X2)}

Tabel 4.10

Semen baturaja memiliki harga yang murah dibandingkan produk semen lainnya

\begin{tabular}{|c|c|c|}
\hline Tingkat Jawaban Responden & Jumlah & Persentase \\
\hline Sangat Setuju & 21 & 21 \\
\hline Setuju & 75 & 75 \\
\hline Netral & -- & -- \\
\hline Tidak Setuju & 4 & 4 \\
\hline Sangat Tidak Setuju & -- & -- \\
\hline TOTAL & 100 & 100 \\
\hline
\end{tabular}

Sumber : Data primer diolah 2021

Berdasarkan tabel tersebut diatas maka dapat dijelaskan bahwa jawaban terbanyak dari responden adalah Setuju dengan jumlah responden sebanyak 75 orang atau sebesar $75 \%$ dan selanjutnya sebanyak 21 orang atau sebesar $21 \%$ responden menyatakan Sangat Setuju dan sebanyak 4 orang atau sebesar $4 \%$ menyatakan Tidak Setuju terhadap pernyataan ini.

Tabel 4.11

Harga yang murah dapat mendorong meningkatkan daya beli konsumen terhadap semen baturaja

\begin{tabular}{|c|c|c|}
\hline Tingkat Jawaban Responden & Jumlah & Persentase \\
\hline Sangat Setuju & 83 & 83 \\
\hline Setuju & 17 & 17 \\
\hline Netral & -- & -- \\
\hline Tidak Setuju & -- & -- \\
\hline Sangat Tidak Setuju & -- & -- \\
\hline TOTAL & 100 & 100 \\
\hline
\end{tabular}

Sumber : Data primer diolah 2021

Berdasarkan tabel tersebut diatas maka dapat dijelaskan bahwa jawaban terbanyak dari responden adalah Sangat Setuju dengan jumlah responden sebanyak 83 orang atau sebesar $83 \%$ dan selanjutnya sebanyak 17 orang atau sebesar $17 \%$ responden menyatakan Setuju terhadap pernyataan ini. 


\section{Variabel Distribusi (X3)}

Tabel 4.12

Semen baturaja mudah didapatkan ditoko bangunan manapun dikota Palembang

\begin{tabular}{|c|c|c|}
\hline Tingkat Jawaban Responden & Jumlah & Persentase \\
\hline Sangat Setuju & 89 & 89 \\
\hline Setuju & 11 & 11 \\
\hline Netral & -- & -- \\
\hline Tidak Setuju & -- & -- \\
\hline Sangat Tidak Setuju & -- & -- \\
\hline TOTAL & 100 & 100 \\
\hline
\end{tabular}

Sumber : Data primer diolah 2021

Berdasarkan tabel tersebut diatas maka dapat dijelaskan bahwa jawaban terbanyak dari responden adalah Sangat Setuju dengan jumlah responden sebanyak 89 orang atau sebesar $89 \%$ dan selanjutnya sebanyak 11 orang atau sebesar $11 \%$ responden menyatakan Setuju terhadap pernyataan ini.

Tabel 4.13

Tidak pernah terjadi kelangkaan semen baturaja di kota Palembang

\begin{tabular}{|c|c|c|}
\hline Tingkat Jawaban Responden & Jumlah & Persentase \\
\hline Sangat Setuju & 78 & 78 \\
\hline Setuju & 20 & 20 \\
\hline Netral & -- & -- \\
\hline Tidak Setuju & 2 & 2 \\
\hline Sangat Tidak Setuju & -- & -- \\
\hline TOTAL & 100 & 100 \\
\hline
\end{tabular}

Sumber : Data primer diolah 2021

Berdasarkan tabel tersebut diatas maka dapat dijelaskan bahwa jawaban terbanyak dari responden adalah Sangat Setuju dengan jumlah responden sebanyak 78 orang atau sebesar 78\% dan selanjutnya sebanyak 20 orang atau sebesar $20 \%$ responden menyatakan Setuju terhadap pernyataan ini dan sebanyak 2 orang atau sebesar $2 \%$ menyatakan Tidak Setuju terhadap pernyataan ini.

\section{Variabel Promosi (X4)}

Tabel 4.14

Saya mengetahui tentang semen baturaja dari iklan televisi dan media sosial

\begin{tabular}{|c|c|c|}
\hline Tingkat Jawaban Responden & Jumlah & Persentase \\
\hline Sangat Setuju & 81 & 81 \\
\hline Setuju & 19 & 19 \\
\hline Netral & -- & -- \\
\hline Tidak Setuju & -- & -- \\
\hline Sangat Tidak Setuju & -- & -- \\
\hline TOTAL & 100 & 100 \\
\hline
\end{tabular}

Sumber : Data primer diolah 2021 
Berdasarkan tabel tersebut diatas maka dapat dijelaskan bahwa jawaban terbanyak dari responden adalah Sangat Setuju dengan jumlah responden sebanyak 81 orang atau sebesar $81 \%$ dan selanjutnya sebanyak 19 orang atau sebesar $19 \%$ responden menyatakan Setuju terhadap pernyataan ini.

Tabel 4.15

Penjual selalu melayani pembelian semen baturaja dengan baik

\begin{tabular}{|c|c|c|}
\hline Tingkat Jawaban Responden & Jumlah & Persentase \\
\hline Sangat Setuju & 28 & 28 \\
\hline Setuju & 72 & 72 \\
\hline Netral & -- & -- \\
\hline Tidak Setuju & -- & -- \\
\hline Sangat Tidak Setuju & -- & -- \\
\hline TOTAL & 100 & 100 \\
\hline
\end{tabular}

Sumber : Data primer diolah 2021

Berdasarkan tabel tersebut diatas maka dapat dijelaskan bahwa jawaban terbanyak dari responden adalah Setuju dengan jumlah responden sebanyak 78 orang atau sebesar $78 \%$ dan selanjutnya sebanyak 22 orang atau sebesar 22\% responden menyatakan Sangat Setuju terhadap pernyataan ini.

Tabel 4.16

Saya seringkali mendapatkan hadiah dari Semen Baturaja

\begin{tabular}{|c|c|c|}
\hline Tingkat Jawaban Responden & Jumlah & Persentase \\
\hline Sangat Setuju & 43 & 43 \\
\hline Setuju & 45 & 45 \\
\hline Netral & -- & -- \\
\hline Tidak Setuju & 12 & 12 \\
\hline Sangat Tidak Setuju & -- & -- \\
\hline TOTAL & 100 & 100 \\
\hline
\end{tabular}

Sumber : Data primer diolah 2021

Berdasarkan tabel tersebut diatas maka dapat dijelaskan bahwa jawaban terbanyak dari responden adalah Setuju dengan jumlah responden sebanyak 45 orang atau sebesar $45 \%$ dan selanjutnya sebanyak 43 orang atau sebesar 43\% responden menyatakan Sangat Setuju terhadap pernyataan ini dan sebanyak 12 orang atau sebesar 12\% responden menyatakan Tidak Setuju.

Tabel 4.17

Semen baturaja sering menjadi sponsorship untuk event-event tertentu

\begin{tabular}{|c|c|c|}
\hline Tingkat Jawaban Responden & Jumlah & Persentase \\
\hline Sangat Setuju & 39 & 39 \\
\hline Setuju & 61 & 61 \\
\hline Netral & -- & -- \\
\hline Tidak Setuju & -- & -- \\
\hline Sangat Tidak Setuju & -- & -- \\
\hline TOTAL & 100 & 100 \\
\hline
\end{tabular}

Sumber : Data primer diolah 2021 
Berdasarkan tabel tersebut diatas maka dapat dijelaskan bahwa jawaban terbanyak dari responden adalah Setuju dengan jumlah responden sebanyak 61 orang atau sebesar 61\% dan selanjutnya sebanyak 39 orang atau sebesar 39\% responden menyatakan Sangat Setuju terhadap pernyataan ini.

\section{B. Variabel Keputusan Konsumen}

Tabel 4.18

Saya telah mengambil keputusan yang tepat dengan memilih semen baturaja sebagai produk andalan

\begin{tabular}{|c|c|c|}
\hline Tingkat Jawaban Responden & Jumlah & Persentase \\
\hline Sangat Setuju & 78 & 78 \\
\hline Setuju & 22 & 22 \\
\hline Netral & -- & -- \\
\hline Tidak Setuju & -- & -- \\
\hline Sangat Tidak Setuju & -- & -- \\
\hline TOTAL & 100 & 100 \\
\hline
\end{tabular}

Sumber : Data primer diolah 2021

Berdasarkan tabel tersebut diatas maka dapat dijelaskan bahwa jawaban terbanyak dari responden adalah Sangat Setuju dengan jumlah responden sebanyak 78 orang atau sebesar $78 \%$ dan selanjutnya sebanyak 22 orang atau sebesar $22 \%$ responden menyatakanSetuju terhadap pernyataan ini.

Tabel 4.19

Sebelum membeli semen baturaja saya berusaha mencari alternatif pilihan produk serupa

\begin{tabular}{|c|c|c|}
\hline Tingkat Jawaban Responden & Jumlah & Persentase \\
\hline Sangat Setuju & 68 & 68 \\
\hline Setuju & 27 & 27 \\
\hline Netral & -- & -- \\
\hline Tidak Setuju & 5 & 5 \\
\hline Sangat Tidak Setuju & -- & -- \\
\hline TOTAL & 100 & 100 \\
\hline
\end{tabular}

Sumber : Data primer diolah 2021

Berdasarkan tabel tersebut diatas maka dapat dijelaskan bahwa jawaban terbanyak dari responden adalah Sangat Setuju dengan jumlah responden sebanyak 68 orang atau sebesar $68 \%$ dan selanjutnya sebanyak 27 orang atau sebesar 27\% responden menyatakanSetuju terhadap pernyataan ini dan sebanyak 5 orang atau sebesar 5\% responden menyatakan Tidak Setuju. 
Tabel 4.20

Saya sudah cukup puas dengan kualitas yang dimiliki semen baturaja

\begin{tabular}{|c|c|c|}
\hline Tingkat Jawaban Responden & Jumlah & Persentase \\
\hline Sangat Setuju & 17 & 17 \\
\hline Setuju & 83 & 83 \\
\hline Netral & -- & -- \\
\hline Tidak Setuju & -- & -- \\
\hline Sangat Tidak Setuju & -- & -- \\
\hline TOTAL & 100 & 100 \\
\hline
\end{tabular}

Sumber : Data primer diolah 2021

Berdasarkan tabel tersebut diatas maka dapat dijelaskan bahwa jawaban terbanyak dari responden adalahSetuju dengan jumlah responden sebanyak 83 orang atau sebesar $83 \%$ dan selanjutnya sebanyak 17 orang atau sebesar 17\% responden menyatakan Sangat Setuju terhadap pernyataan ini.

Tabel 4.21

Semen baturaja memiliki keunggulan yang lebih banyak dibandingkan produk lain

\begin{tabular}{|c|c|c|}
\hline Tingkat Jawaban Responden & Jumlah & Persentase \\
\hline Sangat Setuju & 86 & 86 \\
\hline Setuju & 14 & 14 \\
\hline Netral & -- & -- \\
\hline Tidak Setuju & -- & -- \\
\hline Sangat Tidak Setuju & -- & -- \\
\hline TOTAL & 100 & 100 \\
\hline
\end{tabular}

Sumber : Data primer diolah 2021

Berdasarkan tabel tersebut diatas maka dapat dijelaskan bahwa jawaban terbanyak dari responden adalah Sangat Setuju dengan jumlah responden sebanyak 86 orang atau sebesar $86 \%$ dan selanjutnya sebanyak 14 orang atau sebesar 14\% responden menyatakanSetuju terhadap pernyataan ini.

Tabel 4.22

Saya tidak akan membeli produk semen lain selain semen baturaja

\begin{tabular}{|c|c|c|}
\hline Tingkat Jawaban Responden & Jumlah & Persentase \\
\hline Sangat Setuju & 72 & 72 \\
\hline Setuju & 28 & 28 \\
\hline Netral & -- & -- \\
\hline Tidak Setuju & -- & -- \\
\hline Sangat Tidak Setuju & -- & -- \\
\hline TOTAL & 100 & 100 \\
\hline
\end{tabular}

Sumber : Data primer diolah 2021 
Berdasarkan tabel tersebut diatas maka dapat dijelaskan bahwa jawaban terbanyak dari responden adalah Sangat Setuju dengan jumlah responden sebanyak 72 orang atau sebesar $72 \%$ dan selanjutnya sebanyak 28 orang atau sebesar $28 \%$ responden menyatakanSetuju terhadap pernyataan ini.

Tabel 4.23

Semen baturaja memiliki citra merek yang lebih baik dibandingkan dengan produk lainnya

\begin{tabular}{|c|c|c|}
\hline Tingkat Jawaban Responden & Jumlah & Persentase \\
\hline Sangat Setuju & 53 & 53 \\
\hline Setuju & 47 & 47 \\
\hline Netral & -- & -- \\
\hline Tidak Setuju & -- & -- \\
\hline Sangat Tidak Setuju & -- & -- \\
\hline TOTAL & 100 & 100 \\
\hline
\end{tabular}

Sumber : Data primer diolah 2021

Berdasarkan tabel tersebut diatas maka dapat dijelaskan bahwa jawaban terbanyak dari responden adalah Sangat Setuju dengan jumlah responden sebanyak 53 orang atau sebesar 53\% dan selanjutnya sebanyak 47 orang atau sebesar $47 \%$ responden menyatakanSetuju terhadap pernyataan ini.

\subsection{Pengujian Kualitas Data}

Berdasarkan hasil analisis uji validitas dan reliabilitas variabel penelitian menggunakan program SPSS 22.0 menunjukkan bahwa pengujian validitas dan reliabilitas terhadap instrumen kuesioner dilakukan untuk menjamin bahwa instrumen penelitian yang digunakan tersebut akurat dan dapat dipercaya. Untuk jelasnya kedua pengujian tersebut dapat dijelaskan sebagai berikut:

\section{a. Uji Validitas}

Validitas atau kesahihan menunjukkan sejauh mana suatu alat ukur mampu mengukur apa yang ingin diukur. Uji validitas dihitung dengan membandingkan nilai $r$ hitung (correlated item-total correlation) dengan nilai $\mathrm{r}$ tabel, jika $\mathrm{r}$ hitung $>$ dari $r$ tabel (pada taraf signifikansi $5 \%$ ), maka butir pernyataan dinyatakan valid begitu juga sebaliknya: 
Tabel 4.24

Uji Validitas

\begin{tabular}{|c|c|c|c|c|}
\hline No & Indikator & rhitung & rtabel & Keterangan \\
\hline 1 & $\begin{array}{lc}\text { Produk } \\
\text { - } & \text { Pertanyaan } 1 \\
\text { - } & \text { Pertanyaan2 } \\
\text { - } & \text { Pertanyaan3 } \\
\text { - } & \text { Pertanyaan } 4 \\
\text { - } & \text { Pertanyaan } 5 \\
\text { - } & \text { Pertanyaan } 6\end{array}$ & $\begin{array}{l}0,543 \\
0,653 \\
0,462 \\
0,581 \\
0,665 \\
0,546\end{array}$ & $\begin{array}{l}0,1654 \\
0,1654 \\
0,1654 \\
0,1654 \\
0,1654 \\
0,1654\end{array}$ & $\begin{array}{l}\text { Valid } \\
\text { Valid } \\
\text { Valid } \\
\text { Valid } \\
\text { Valid } \\
\text { Valid }\end{array}$ \\
\hline 2 & $\begin{array}{l}\text { Harga } \\
\text { - } \quad \text { Pertanyaan1 } \\
\text { - } \quad \text { Pertanyaan2 }\end{array}$ & $\begin{array}{l}0,654 \\
0,663\end{array}$ & $\begin{array}{l}0,1654 \\
0,1654\end{array}$ & $\begin{array}{l}\text { Valid } \\
\text { Valid }\end{array}$ \\
\hline 3 & \begin{tabular}{ll}
\multicolumn{2}{l}{ Distribusi } \\
- & Pertanyaan1 \\
- & Pertanyaan2 \\
- & Indikator3
\end{tabular} & $\begin{array}{l}0,633 \\
0,546 \\
0.543\end{array}$ & $\begin{array}{l}0,1654 \\
0,1654 \\
0,196 \\
0,196\end{array}$ & $\begin{array}{l}\text { Valid } \\
\text { Valid }\end{array}$ \\
\hline 4 & \begin{tabular}{lc}
\multicolumn{2}{l}{ Promosi } \\
- $\quad$ Pertanyaan 1 \\
- $\quad$ Pertanyaan2 \\
- $\quad$ Pertanyaan3 \\
- $\quad$ Pertanyaan 4
\end{tabular} & $\begin{array}{l}0,478 \\
0,546 \\
0,511 \\
0,687\end{array}$ & $\begin{array}{l}0,1654 \\
0,1654 \\
0,1654 \\
0,1654 \\
0,196 \\
0,196\end{array}$ & $\begin{array}{l}\text { Valid } \\
\text { Valid } \\
\text { Valid } \\
\text { Valid }\end{array}$ \\
\hline 5 & 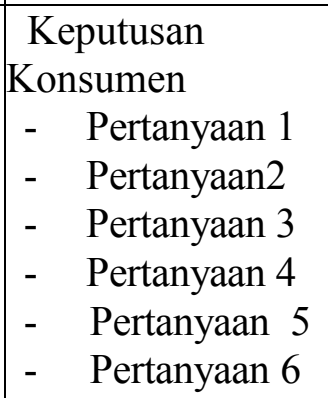 & $\begin{array}{l}0,661 \\
0,576 \\
0,763 \\
0,611 \\
0,509 \\
0,677\end{array}$ & $\begin{array}{l}0,1654 \\
0,1654 \\
0,1654 \\
0,1654 \\
0,1654 \\
0,1654\end{array}$ & $\begin{array}{l}\text { Valid } \\
\text { Valid } \\
\text { Valid } \\
\text { Valid } \\
\text { Valid } \\
\text { Valid }\end{array}$ \\
\hline
\end{tabular}

Sumber:Dataprimeryang diolah2021

Tabel 4.24 menunjukkan bahwa semua indikator yang digunakan untuk mengukur variabel-variabel yang digunakan dalam penelitian ini mempunyai nilai korelasi yang lebih besar dari 0,1654. Dari hasil tersebut menunjukkan bahwa semua indikator tersebut adalah valid. 


\section{b. Uji Reabilitas}

Untuk menguji reliabilitas dilakukan dengan menggunakan Koefisien Reliabilitas (Cronbach Alpha). Hasil uji reliabilitas instrumen kuesioner sebagaimana yang terdapat dalam lampiran skripsi ini dapat disimpulkan dalam Tabel 4.25 berikut ini

Tabel 4.25

\section{HasilPengujianReliabilitas}

\begin{tabular}{|l|c|c|}
\hline \multicolumn{1}{|c|}{ Variabel } & Alpha & Keterangan \\
\hline Produk & 0,732 & Reliabel \\
\hline Harga & 0,765 & Reliabel \\
\hline Distribusi & 0,812 & Reliabel \\
\hline Promosi & 0,756 & Reliabel \\
\hline Keputusan Konsumen & 0,846 & Reliabel \\
\hline
\end{tabular}

Sumber:Dataprimeryangdiolah,2021

Berdasarkan Tabel 4.25 diatas, menunjukkan bahwa nilai alpha instrumen penelitian pada masing-masing variabel lebih besar dari nilai yang diisyaratkan, yaitu sebesar 0.60 atau lebih besar dari 0.60. Dengan demikian, keseluruhan instrumen kuesioner dalam penelitian ini adalah reliable (dapat dipercaya) karena telah memenuhi syarat minimal.

\subsection{Analisis Regresi Linier Berganda}

Hasil perhitungan dengan menggunakan model regresi penuh (Full Model Regression) diperoleh dengan nilai koefisien regresi pengaruh strategi pemasaran dalam pengambilan keputusan konsumen dalam melakukan pembelian Semen Baturaja di kota Palembang.

Tabel 2.26

Hasil Analisis Regresi Linier Berganda

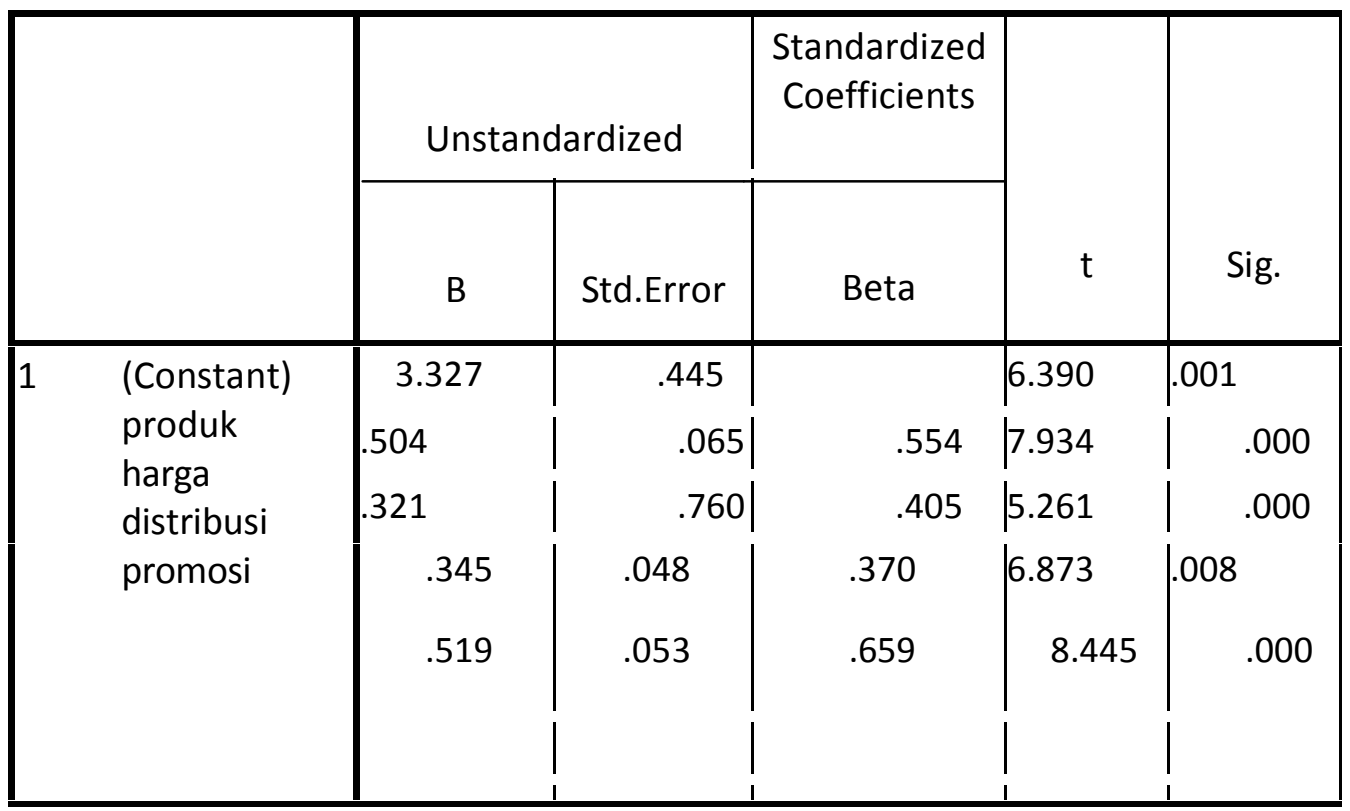

a. DependentVariable:keputusan konsumen 
Berdasarkan perhitungan dengan bantuan program SPSS menggunakan Full Model Regression diperoleh persamaan regresinya adalah sebagai berikut:

$$
\begin{aligned}
Y= & 3,327+0,504 X 1+0,321 X 2+0,345 \\
& \text { X3 }+0,519 X 4
\end{aligned}
$$

Persamaan regresi tersebut dapat dejelaskan sebagai berikut :

1. Konstanta sebesar 3,327 artinya jika Strategi Pemasaran yang terdiri dari Bukti Produk (X1), Harga (X2), Distribusi (X3), dan Promosi (X4) adalah nol maka Keputusan Konsumen (Y) nilainya adalah 3,327 .

2. Koefisien regresi variabel Produk (X 1 ) sebesar 0,504 artinya jika variabel independen lainnya nilainya tetap dan nilai produk (X1) mengalami kenaikan 1\% maka nilai Keputusan Konsumen akan meningkat sebesar 50,4\%.

3. KoefisienregresivariabelHarga( X 2 ) sebesar 0,321 artinya jika variabel independen lainnya nilainya tetap dan nilai Harga (X2) mengalami kenaikan 1\% maka nilai Keputusan Konsumen akan meningkat sebesar 32,1\%.

4. Koefisien regresi variabel Distribusi (X 3 ) sebesar 0,345 artinya jika variabel independen lainnya nilainya tetap dan nilai Distribusi (X3) mengalami kenaikan $1 \%$ maka nilai Keputusan Konsumen meningkat sebesar 34,5\%.

5. Koefisien regresi variabel Promosi (X 4 ) sebesar 0,519 artinya jika variabel independen lainnya nilainya tetap dan niai Promosi (X4) mengalami kenaikan 1\% maka nilai Keputusan Konsumen akan meningkat sebesar $51,9 \%$.

\subsection{Pengujian Hipotesis}

4.4.1. Uji t (Pengujian hipotesis secara parsial)

Untuk menguji keberartian model regresi untuk masing-masing variabel secara parsial dapat di peroleh dengan menggunakan uji t. Berikut akan dijelaskan pengujian masing-masing variabel secara parsial

\section{Variabel Produk}

Hasil pengujian diperoleh nilai $t$ untuk variabel produk menunjukkan nilai $\mathrm{t}=7,934>\mathrm{t}$ tabel $=1,984$ dengan nilai signifikansi sebesar $0,000<0,05$. Dengan nilai signifikansi dibawah 0,05 tersebut menunjukkan bahwa variabel produk memiliki pengaruh yang signifikan terhadap Keputusan Konsumen. Hal ini berarti Hipotesis 1 diterima. Arah diterima. Arah koefisien regresi positif berarti bahwa produk memiliki pengaruh positif yang signifikan terhadap Keputusan Konsumen.

\section{Variabel Harga}

Hasil pengujian diperoleh nilai $t$ untuk variabel harga menunjukkan nilai $\mathrm{t}=5,261>\mathrm{t}$ tabel $=1,984$ dengan nilai signifikansi sebesar $0,000<0,05$. Dengan nilaisignifikansi dibawah 0,05 tersebut menunjukkan bahwa variabel harga memiliki pengaruh yang signifikan terhadap Keputusan Konsumen. Hal ini berarti Hipotesis 2 diterima. Arah diterima. Arah koefisien regresi positif berarti bahwa harga memiliki pengaruh positif yang signifikan terhadap Keputusan Konsumen.

\section{Variabel Distribusi}

Hasil pengujian diperoleh nilai $t$ untuk variabel distribusi menunjukkan nilai $\mathrm{t}=6,873>\mathrm{t}$ tabel $=1,984$ dengan nilai signifikansi sebesar $0,008<0,05$. Dengan nilai signifikansi dibawah 0,05 tersebut menunjukkan bahwa variabel distribusi memiliki pengaruh yang signifikan terhadap Keputusan Konsumen. Hal ini berarti Hipotesis 3 diterima. Arah diterima. Arah koefisien regresi positif berarti bahwa distribusi memiliki pengaruh positif yang signifikan terhadap Keputusan Konsumen. 


\section{Variabel Promosi}

Hasil pengujian diperoleh nilai $t$ untuk variabel promosi menunjukkan nilai $\mathrm{t}=8,445>\mathrm{t}$ tabel $=1,984$ dengan nilai signifikansi sebesar $0,000<0,05$. Dengan nilai signifikansi dibawah 0,05 tersebut menunjukkan bahwa variabel promosi memiliki pengaruh yang signifikan terhadap Keputusan Konsumen. Hal ini berarti Hipotesis 4 diterima. Arah diterima. Arah koefisien regresi positif berarti bahwa promosi memiliki pengaruh positif yang signifikan terhadap Keputusan Konsumen.

\subsubsection{Ujif (Pengujian hipotesis secara simultan)}

Hasil perhitungan regresi secara simultan (bersama-sama) dapat dilihat pada Tabel 4.27 berikut :

Tabel 4.27

\section{Hasil Analisis Secara Simultan}

\begin{tabular}{|l|r|r|r|r|r|}
\hline \multirow{2}{*}{ Model } & \multicolumn{1}{c|}{$\begin{array}{c}\text { Sumof } \\
\text { Squares }\end{array}$} & df & MeanSquare & $\mathrm{F}$ & \multicolumn{1}{c|}{ Sig. } \\
\hline 1 Regression \\
Residual & 42.456 & 4 & 15.354 & 77.763 & $.000^{\mathrm{a}}$ \\
Total & 34.221 & 95 & .347 & & \\
& 76.667 & 99 & & & \\
\hline
\end{tabular}

a.Predictors:(Constant), produk, harga,distribusi,promosi

b.DependentVariable:Keputusan Konsumen

Pengujian pengaruh variabel bebas secara bersama-sama terhadap variabel terikatnya dilakukan dengan menggunakan uji F. Hasil perhitungan statistik menunjukkan nilai $\mathrm{F}$ hitung $=77,763>\mathrm{F}$ tabel $=2,469$ dengan signifikansi sebesar $0,000<0,05$. Dengan nilai signifikansi dibawah 0,05 menunjukkan bahwa secara bersama-sama variabel produk, harga, distribusi, dan promosi mempunyai

pengaruh yang positif dan signifikan terhadap keputusan konsumen.

\subsubsection{Koefisien Determinasi}

Koefisien determinasi ini digunakan untuk mengetahui seberapa besar pengaruh variabel-variabel bebas memiliki pengaruh terhadap variabel terikatnya. Nilai koefisien determinasi ditentukan dengan nilai adjusted $R$ square

Tabel 4.28

Koefisien Determinasi

Model Summary ${ }^{b}$

\begin{tabular}{|c|r|r|c|c|}
\hline Model & \multicolumn{1}{|c|}{ R } & R Square & Adjusted R & Std.Error of the \\
\hline 1 & $.704^{\mathrm{a}}$ & .54 & .532 & 1.18147 \\
\hline
\end{tabular}

a. Predictors: (Constant), produk, harga, distribusi, promosi

b. Dependent Variable: Keputusan Konsumen 
Hasil perhitungan regresi dapat diketahui bahwa koefisien determinasi $\left(R^{2}\right)$ yang diperoleh sebesar 0,547 . Hal ini berarti $54,7 \%$ keputusan konsumen dipengaruhi oleh produk, harga, distribusi dan promosi, sedangkan sisanya yaitu 48,3\% keputusan konsumen dipengaruhi oleh variabelvariabel lainnya yang tidak diteliti dalam penelitian ini.

\subsection{Pembahasan}

\section{Pengaruh Produk Terhadap Keputusan Konsumen Membeli Semen Baturaja}

Berdasarkan Uji t pada tabel 2.25 didapatkan koefisien pengaruh variabel produk terhadap keputusan konsumen adalah $\mathrm{t}=7,934>\mathrm{t}$ tabel $=1,984$ dengan tingkat signifikansi $(\mathrm{sig})=0,000<0,05$. Ini menunjukan bahwa variabel produk berpengaruh terhadap keputusan konsumen. Jadi produk berpengaruh signifikan terhadap keputusan pembelian konsumen terhadap Semen Baturaja. Ini mengindikasikan bahwa makin baik kualitas produk Semen Baturaja maka akan menyebabkan konsumen akan makin cenderung memilih semen baturaja dibandingkan dengan merek lain.

Selain itu, permintaan konsumen bukan hanya dipengaruhi oleh harga melainkan juga dapat dipengaruhi oleh faktor pendapatan, selera dan lain sebagainya disini tentu sangat berkaitan dengan produk. Jadi jika produk semen baturaja sesuai dengan selera kualitasnya, maka konsumen akan memutuskan untuk berulang membeli. Hal ini juga dapat didukung oleh teori perilaku konsumen dimana konsumen akan memaksimumkan kepuasannya dengan keterbatasan pendapatannya. Nilai guna produk menentukan minat konsumen terhadap produk. Nilai guna produk tersebut adalah bagian dari produk, jadi jika nilai guna produk meningkat maka produk tersebut juga akan meningkat.

\section{Pengaruh Harga Terhadap Keputusan Konsumen Membeli Semen Baturaja}

Berdasarkan Uji t pada tabel 2.25 didapatkan koefisien pengaruh variabel harga terhadap keputusan konsumen adalah $\mathrm{t}=5,261>\mathrm{t}$ tabel $=1,984$ dengan tingkat signifikansi $(\mathrm{sig})=0,040<0,05$. Inimenunjukkan bahwa variabel harga berpengaruh terhadap keputusan pembelian. Jadi harga berpengaruh signifikan terhadap keputusan pembelian Semen Baturaja.Ini mengindikasikan bahwa makin murah Semen Baturaja menyebabkan konsumen akan makin memilih Semen Baturaja.Ini menunjukkan bahwa variabel harga berpengaruh positifdan signifikan terhadap keputusan konsumen.

\section{Pengaruh Distribusi Terhadap Keputusan Konsumen Membeli Semen Baturaja}

Berdasarkan Uji t pada tabel 2.25 didapatkan koefisien pengaruh variabel distribusi terhadap keputusan konsumen adalah $\mathrm{t}=6,873>\mathrm{t}$ tabel $=1,984$ dengan tingkat signifikansi $(\mathrm{sig})=0,008<0,05$. Ini menunjukkan bahwa variabel distribusi berpengaruh terhadap keputusan konsumen. Jadi distribusi berpengaruh signifikan terhadap keputusan pembelian semen baturaja di kota Palembang. Ini mengindikasikan bahwa apabila distribusi semen baturaja ditingkatkan maka akan meningkatkan keputusan pembelian konsumen terhadap semen baturaja.

Hal ini dapat diperkuat oleh data penjualan semen baturaja di kota Palembang dari tahun ke tahun.Secara rasional, walaupun konsumen memutuskan untuk membeli semen baturaja tapi jika tidak ada di pasaran atau susah didapatkan maka konsumen dapat mencari produk subtitusi 
yakni semen merek lain sebagai produk subtitusi dan pesaing utama seperti.

Pendistribusian semen baturaja dilakukan dengan menyalurkannya ke seluruh retailer/toko-toko bangunan di Kota Palembang dan di daerah kabupatendi Provinsi Sumatera Selatan pada khususnya.Semua ini dilakukan dalam rangka memberikan pelayanan yang baik terhadap konsumen.

\section{Pengaruh Promosi Terhadap Keputusan Konsumen Membeli Semen Baturaja}

Berdasarkan Uji t pada tabel 2.25 didapatkan koefisien pengaruh variabel promosi terhadap keputusan konsumen adalah $\mathrm{t}=8,445>\mathrm{t}$ tabel $=1,984$ dengan tingkat signifikansi $(\mathrm{sig})=0,000<0,05$. Ini ditunjukan bahwa variabel promosi berpengaruh terhadap keputusan konsumen. Jadi promosi berpengaruh signifikan terhadap keputusan pembelian semen baturaja di Kota Palembang. Ini mengindikasikan bahawa apabila promosi semen baturaja ditingkatkan maka akan meningkatkan keputusan pembelian konsumen terhadap semen baturaja.

\section{KESIMPULAN DAN SARAN}

\section{A. Kesimpulan}

Berdasarkan hasil penelitian dan pembahasan, maka dibuat simpulansebagai berikut:

1. Strategi pemasaran yang terdiri atas produk, harga, distribusi dan promosi secara siultan berpengaruh terhadap keputusan pembelian Semen Baturaja di Kota Palembang dengan nilai koefisien determinasi $\mathrm{R}$ Square $=0,547$. Ini mengindikasikan bahwa $54,7 \%$ variasi dari variabel keputusan pembelian ditentukan (dipengaruhi) oleh produk, harga, distribusi dan promosi. Jadi masihada variabel bebas yang lain yang berpengaruh terhadap keputusan pembelian yang tidak dimasukkan dalam model analisis. Besarnya variasi dari keputusan pembelian yang dapat ditaksir oleh variabel lain adalah $45,3 \%$

2. Strategi pemasaran yang terdiri atas produk, harga, promosi dandistribusi semuanya secara parsial berpengaruh terhadap keputusan pembelian Semen Baturaja di Kota Palembang. Ini menunjukkan bahwa makin baik produk, harga makin murah,promosi makin baik, dan distribusi makin banyak dan baik masing-masing dapat meningkatkan minat dan keputusan pembelian Semen Baturaja di Kota Palembang.

3. Faktor yang dominan berpengaruh terhadap keputusan pembelian Semen Baturaja di Kota Palembang adalah promosi. Ini mengindikasikan bahwa jika nilai produk, harga, promosi dan distribusi dinaikkan dengan besaran yang sama, maka kenaikan nilai keputusan pembelian konsumen paling besar ditentukan oleh promosi.

\section{B. Saran}

Berdasarkan hasil penelitian ini, maka dikemukakan saran sebagaiberikut:

1. Disarankan kepada PT.Semen Baturaja Persero (Tbk) sebagai produsen untuk senantiasa memperhatikan dan melakukan perbaikan terhadap produk, promosi dan distribusi Semen Baturaja di Kota Palembang. Selain itu hendaknya pula memperhatikan harga Semen Baturaja yakni bisa bersaing dengan harga semen merek yang lain dan dapat dijangkau oleh masyarakat. Usahakan agar menjadi leader market di kelasnya dengan mengungguli penjulan produk-produk semen lainnya.

2. Dari keempat strategi pemasaran yang ada yaitu produk, harga, distribusi dan promosi, maka yang utama diperhatikan 
dan ditingkatkan terus adalah promosi. Promosi bisa dilakukan dengan menggunakan semua media, khususnya penggunaan media sosial yang dapat menjangkau masyarakat secara luas.

3. Diharapkan penelitian ini dapat menjadi dasar landasan teoritis bagi penelitian selanjutnya baik dengan objek yang sama ataupun berbeda dan tentu dengan pengembangan aspek pemasaran lainnya sehingga akan memperkaya khasanah teori-teori tentang pemasaran.

\section{DAFTAR PUSTAKA}

Azwar, Saefuddin. 2017. Reliabilitas dan Validitas. Edisi Ketiga. Pustaka Pekerja, Yogyakarta

Irawan dan Basu, Swastha. 2018. Manajemen Pemasaran Modern, Cetakan ke 13, Liberty, Yogyakarta

Kotler, Philip, 2019. Manajemen Pemasaran, Analisis Perencanaan, Implementasi dan Kontrol. Edisi 9 PT. Prenhallindo, Jakarta.

------------,2018.Marketing Management. The Millennium Edition.Prentice Hall, Inc. New Jersey.

-,2019.Manajemen Pemasaran. Edisi 1 dan 2. Penerbit Prenhallindo, Jakarta.

Kotler, Philip dan Amstrong, Gary 2014, Dasar-Dasar Pemasaran, Alih Bahasa: Alexander Sindoro, Edisi Indonesia, Prehalindo, Jakarta

Nitisemito, Alex. S. 2018. Marketing. Jakarta: Ghalia Indonesia.

Ruseffendi, M, 2014.Praktis dalam Membuat Instrumen Penelitian. Penerbit Elex Media Komputindo, Jakarta.
Swastha, Basu, 2014. Konsep Pemasaran: Sikap dan Perilaku Pemasar. Penerbit Elex Media Komputindo, Jakarta.

Tjiptono 2015, Strategi Pemasaran, Cetakan Kelima, Andi, Yogyakarta

Umar, Husain. 2013. Riset Pemasaran \& Perilaku Konsumen. Cetakan ketiga. PT Gramedia Pustaka Utama, Jakarta

Winardi, 2019.Strategi Pemasaran. Cetakan Pertama, Penerbit Mandar Maju, Bandung.

Zain, Umar, 2017. Manajemen Jasa. Andi, Yogyakarta 